\title{
Gezocht: freelance journalist of pedicure met journalistieke vaardigheden
}

Podopost is op zoek naar uitbreiding van haar netwerk freelance journalisten die kennis hebben van de pedicurebranche of naar pedicures met uitstekende journalistieke vaardigheden.

- Je verstaat de kunst van het interviewen als geen ander.

- Je vindt het geen probleem om mensen op verschillende locaties in Nederland te interviewen.

- Je bent in staat om prettig leesbare artikelen naar journalistieke maatstaven te maken.

- Je draait ook je hand niet om voor meer vakinhoudelijke artikelen en casusbeschrijvingen.

- Je bent in staat om zelfstandig te werken en om onderzoek voor je artikelen te verrichten.

- Je hebt kennis van de pedicurebranche.

- Je bent prettig in de omgang.

- Je legt gemakkelijk contacten.

- Je bent nauwkeurig en komt je afspraken na.

Interesse?

Stuur je reactie met CV en motivatie naar:

Sylvia de Bruijn

podopost@bsl.nl

030-6383880
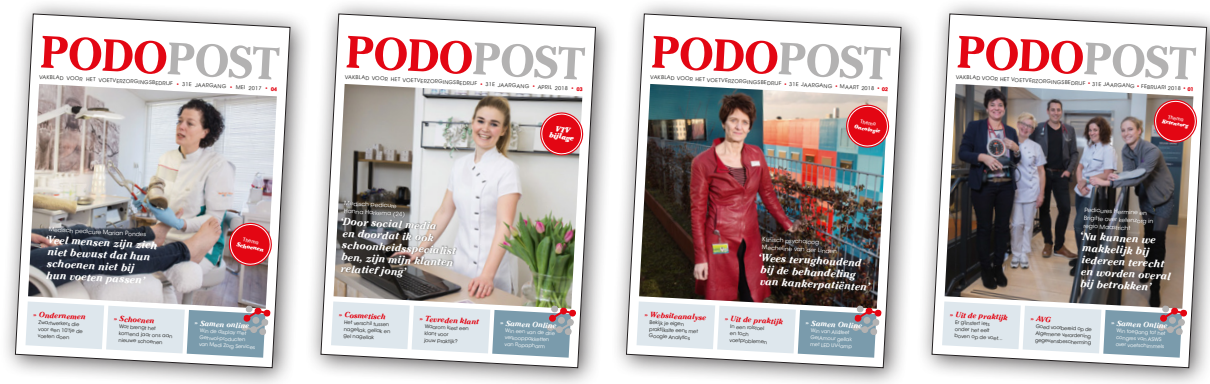

bohn

stafleu

van loghum

bohn stafleu van loghum

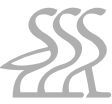

bohn

stafleu

van loghum

cCe bohn stafleu

van loghum

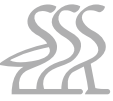

bohn

stafleu

van loghum

cC bohn stafleu

van loghum

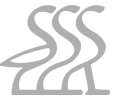

bohn

stafleu

van loghum

cCe bohn

stafleu

van loghum

CCS bohn

stafleu

van loghum

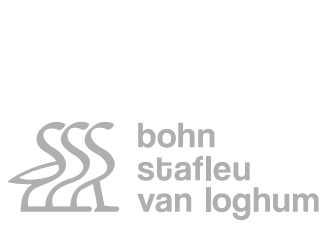

van loghum

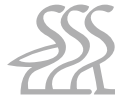

bohn

stafleu

van loghum

bohn

stafleu

van loghum
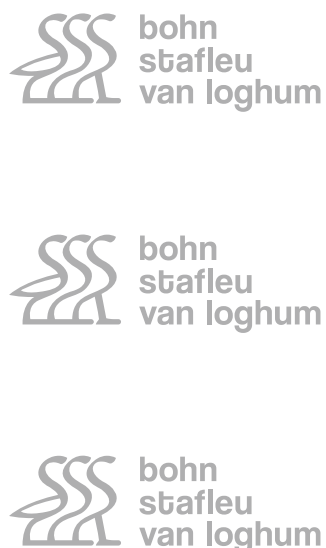

bohn

stafleu

van loghum

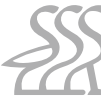

bohn

stafleu

van loghum

bohn

stafleu

van loghum

bohn

stafleu

van loghum

bohn

stafleu

van loghum

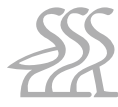

bohn stafleu van loghum

stafleu van loghum
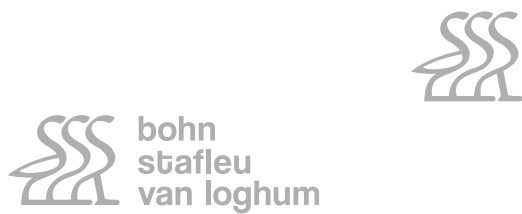

bohn stafleu van loghum

bohn stafleu van loghum

bohn stafleu van loghum 